\title{
The Electron Microscopy of Micro-Dispersed Colloid Silver Nanoparticles
}

\author{
Ignat Ignatov $^{1 *} \quad$ Oleg Mosin ${ }^{2}$ \\ 1. Scientific Research Center of Medical Biophysics (SRCMB), \\ N. Kopernik Street, 32, Sofia 1111, Bulgaria \\ 2. Biotechnology Department, Moscow State University of Applied Biotechnology, \\ Talalikhina Street, 33, Moscow 109316, Russian Federation \\ * E-mail of the corresponding author: mbioph@ dir.bg
}

\begin{abstract}
In this paper are studied the methods for preparation of micro dispersed colloid silver nanoparticles and scopes of their practical application in nano-industry, bionanotechnology, medicine and allied industries, including water processing and water purification techniques. The mechanisms of bactericidal influence of colloid silver on a microbial cell are discussed from the point of view of absorptive, electrostatic, enzyme and mutagen theories. Silver exerts both bactericidal and bacteriostatic effect against more than 500 species of microorganisms. The effect of bacterial destruction by silver is 1500 times more than the same concentration of phenol and 3.5 times more than the action of mercuric chloride. It is demonstrated that effects of colloid silver are defined by the concentration, the sizes of micro dispersed nanoparticles and their stability in water solutions. The silver nanoparticles in their turn may be prepared by using various physico-chemical, biochemical and biotechnological methods.
\end{abstract}

Key words: colloid silver, nanoparticles, bionanotechnology, water treatment.

\section{Introduction}

Silver $(\mathrm{Ag})$ - is a metal with an atomic mass 107.87 a.u.e. related to the sub-group of the first group of the periodic system, has a pronounced physiological effect on the body.

A wide range of antimicrobial action of silver, no resistance toward it by the majority of pathogens, low toxicity, absence of allergens and their being well tolerated by patients contributed to the increased interest toward silver in this country and the creation of various anti-inflammatory medications having antiseptic and bactericidal action based on it, as progatol, collargol etc. (Savadyan et al., 1989).

At the end of XIX century Swiss botanist Karl Nagel (Nägeli, 1893) found that the cause of bactericidal effect of silver on cells of microorganisms are ions $\mathrm{Ag}^{+}$. This phenomenon is denoted oligodinamiey (from the Greek "oligos" - small, the trace, and "dynamos" - action). Silver exerts oligodynamic effect only in dissolved, ionized form. It was established that silver exerts the most strong bactericidal action in the following row of heavy metals "copper-silver-gold", and less — copper and gold (Shrestha et al., 2009). S.S. Botkin and A.P. Vinogradov explained this effect by dependence of biological properties of trace elements from the position they occupy in the periodic table. In the works of L.A. Kulsky and subsequently other researchers, it was shown that the destruction of microorganisms cause not only $\mathrm{Ag}^{+}$ions, but their dissociated compounds - substances capable of disintegrating in aqueous solutions to charged ions (Kulsky, 1987).

$\mathrm{Ag}^{+}$silver ions and colloidal solutions (suspensions of micro dispersed silver nanoparticles) possess bactericidal, bacteriostatic, antiviral, antifungal and antibacterial activity against more than 500 pathogenic microorganisms, yeast, fungi and viruses (Bryzgunov et al., 1964). Their antimicrobial effect is slightly stronger than the penicillin, biomitsin and other antibiotics due to the inhibitory effect on antibiotic resistant strains of bacteria (Shahverdy et al., 2007). Thus, the bacteria-annihilating effect of silver is 1500 times higher than that one of the phenol concentration in the same concentration, and 3.5 times higher than that of mercuric chloride. $\mathrm{Ag}^{+}$ions exert an antimicrobial effect from bacteriostatic (ability to inhibit microbial growth) to bactericidal (the ability to destroy microbes) on many pathogen microorganisms as Staphylococcus aureus, Streptococcus, Proteus vulgaris, Pseudomonas and Escherichia coli (Landsdown, 2010). $\mathrm{Ag}^{+}$has pronounced antifungal activity at concentration of $0,1 \mathrm{mg} / \mathrm{l}$ : at the microbial load of 100 000 cells per 1 liter the destruction of pathogenic yeast of Candida albicans occurs within 30 minutes after contact with the metallic silver.

The activity of samples of colloidal silver depends directly on the concentration of $\mathrm{Ag}^{+}$ions and the amount of silver nanoparticles in aqua solutions: at concentration of $\mathrm{Ag}^{+} 1 \mathrm{mg} / \mathrm{l}$ Escherichia coli get killed after $3 \mathrm{~min}$., at $0.5 \mathrm{mg} / \mathrm{l}$ - after $20 \mathrm{~min}$., at $0.2 \mathrm{mg} / \mathrm{l}-50 \mathrm{~min}$., and at $0.05 \mathrm{mg} / \mathrm{l}-2$ hours. The sensitivity to silver pathogenic 
and nonpathogenic microorganisms is varied; the first group of microorganisms has higher levels of sensitivity toward silver (Belevantsev \& Bondarchuk, 1994). With keeping this in mind, in this country, a method of treatment of dysbiosis of various etiology is developed based on abdominal electrophoresis of $\mathrm{Ag}^{+}$ions (concentration - $500 \mathrm{mg} / \mathrm{l}$ ) that allows to achieve a stable therapeutic effect (Mironenko, 1971).

There is evidence that $\mathrm{Ag}^{+}$ions have the ability to inactivate viruses of pox, influenza $\mathrm{A} 1, \mathrm{~B}$, and some enteric adenoviruses in vitro (Mironenko, 1971), as well as to exert a therapeutic effect in the treatment of viral enteritis, and inhibit HIV virus at an early stage of development (Obukhov, 1994). Thus, $1 \mathrm{mg} / \mathrm{l}$ of colloid micro dispersed silver in the aqueous solution within 30 min causes inactivation of influenza viruses $A 1, B$, Mitra and Sendai. Therefore, it is obvious the significant advantage of using colloidal silver $\mathrm{Ag}^{+}$in comparison with conventional antibiotic therapy, because silver has no significant side effects.

Silver and its colloid solutions may also be applied as effective antibacterial agents in direct contact with the surface wounds and inflammation and bacterial infection suppurating portions (Vitsyn et al., 1976). The results of the application of colloidal silver solutions show the effectiveness of their use in the treatment of gastrointestinal diseases, cholecystitis, infectious hepatitis, cholangitis, pancreatitis, duodenitis and intestinal infections (Glazov et al., 1986). The solution of colloidal silver can also be used for stomach ulcers and duodenal ulcers, because in this case is destroyed bacterium Helicobacter pilori, populating the mucous membranes of the stomach and intestines, responsible for erosive and ulcerative processes in the gastrointestinal tract (Loginov, 1999). Unlike ionic silver that getting into the digestive tract, forming insoluble salts precipitated and loses its bactericidal activity, the colloidal silver nanoparticles stabilized in aqueous solutions, are more resistant and can operate for long periods of time.

It should be noted that silver as a micro element is included in the body tissues, endocrine glands, liver and brain. Thus the human body contains approximately 20 micrograms of silver per $100 \mathrm{~g}$ of dry matter (Vaynar, 1960). According to various sources, the physiological norm of silver in organism compiles from $20 \mathrm{mg}$ to 40 mg (Ignatov \& Mosin, 2013).

The high biological activity of microelements in the human body is associated with their participation in the synthesis of enzymes and hormones. Depending on the concentration of ions in aqueous solutions, $\mathrm{Ag}^{+}$ions can both stimulate and inhibit the activity of some enzymes. Under their influence the intensity of amplified oxidative phosphorylation in mitochondria in brain tissues is increased on almost twice, as well as the nucleic acid content is increased that improves the supply of oxygen to brain cells (Chappel \& Greville, 1964).

During the incubation of various cellular tissues in normal saline containing $0,001 \mu \mathrm{g} \mathrm{of} \mathrm{Ag}^{+}$, the brain tissue absorbs on $24 \%$ more oxygen, myocardium - $20 \%$, liver - $36 \%$ kidney $-25 \%$. A further increase in the concentration of $\mathrm{Ag}^{+}$ions to $0.01 \mu \mathrm{g}$ reduces the absorption of oxygen by cells of these organs, indicating about the regulation of energy metabolism by $\mathrm{Ag}^{+}$ions according to the type of feedback mechanism. In studying the effects of drugs based on colloidal silver on the human body it was noted their stimulating effect on the composition of blood: neutrophils forms in blood are disappeared; it was shown some increase in the number of lymphocytes and monocytes, red blood cells and hemoglobin while deceleration of erythrocyte sedimentation rate (Obukhov, 1992).

In recent years in the scientific literature are appeared data on the immunomodulatory properties of silver (Volski et al., 1992). It was demonstrated that, depending on the concentration silver may stimulate or inhibit cell phagocytosis. Under the influence of silver the amount of immunoglobulin classes of $A, M, G$ increases, as well as increases the amount of $T$-lymphocytes.

Significant factor in the use of colloidal silver is that the concentration of $\mathrm{Ag}^{+}$at $50-250 \mathrm{mg} / \mathrm{l}$, close to the maximum permissible has no adverse effects on the organism (Mosin \& Ignatov, 2014.). At prolonged intake of $\mathrm{Ag}^{+}$ions in the diet occurs the accumulation of $\mathrm{Ag}^{+}$in tissues of the human body - argyria, which is the result of photochemical reduction of $\mathrm{Ag}^{+}$ions (Roschin \& Ordzhonikidze, 1984). The essential influence on the development of argyria has individual susceptibility of organism to silver, the body's immune status and other factors.

The above-mentioned factors suggest that silver plays a significant role in the biochemical processes and can be considered as a trace element necessary for normal functioning of internal organs and systems, as well as an enhancing agent to the immune system, which has a strong impact on numerous pathogens. Therefore, it is promising the development and improvement of new bionanotechnology approaches for obtaining micro dispersed silver nanoparticles for medicine, nanotechnology industry and water treatment, as well as the study of the nanostructure of silver nanoparticles and their physical-chemical properties.

The aim of the research was to examine the mechanisms of the biological action of silver on cell, the methods of preparation of micro dispersed silver nanoparticles, as well as searching for possible areas of practical application of silver nanoparticles. 


\section{Experimental Part}

\section{Material}

The study was performed with samples of micro-dispersed nanoparticles obtained from Russian Joint Company "Nano-Bio-Technology" (Moscow, Russia). The samples were taken and analyzed in solid samples according to National standard of the Russian Federal Agency of Technical Regulation and Metrology.

\section{Analytical methods}

\section{Transmission electron microscopy}

The structural studies were carried out with using transmission electron microscopy (TEM) on JSM 35 CF (JEOL Ltd., Korea) device, equipped with X-ray microanalyzer "Tracor Northern TN", SE detector, thermomolecular pump, and tungsten electron gun (Harpin type $\mathrm{W}$ filament, DC heating); working pressure: $10^{-4}$ $\mathrm{Pa}\left(10^{-6}\right.$ Torr); magnification: 300000 , resolution: $3,0 \mathrm{~nm}$, accelerating voltage: $1-30 \mathrm{kV}$; sample size: $60-130$ $\mathrm{mm}$.

\section{Results and Discussion}

\subsection{The mechanism of action of $\mathrm{Ag}^{+}$ions on microbial cell}

The basic physical properties of the metallic silver are demonstrated in Table below.

Table: The basic physical properties of the metallic silver

\begin{tabular}{|l|l|}
\hline Physical property & Value \\
\hline Atomic mass, a.u.e & 107,87 \\
\hline Density, g/cm ${ }^{3}$ & 10,49 \\
\hline Melting point, ${ }^{0} \mathrm{C}$ & 960,5 \\
\hline Boiling point, ${ }^{0} \mathrm{C}$ & 2210,0 \\
\hline Latent heat of fusion, cal/g & 25,0 \\
\hline Specific heat, cal $/\left(\mathrm{g}^{0} \mathrm{C}\right)$ & 0,056 \\
\hline Electrical resistivity, $\mu \mathrm{Om} \cdot \mathrm{cm}$ & 1,62 \\
\hline Thermal conductivity, cal $/\left(\mathrm{cm}^{\circ}{ }^{0}{ }^{0} \mathrm{C}\right)$ & 0,974 \\
\hline
\end{tabular}

Due to the presence of hydrogen sulfide in the air the metallic silver eventually get oxidized, covered with a dark touch of silver sulfide $\left(\mathrm{Ag}_{2} \mathrm{~S}\right)$ :

$$
4 \mathrm{Ag}+\mathrm{O}_{2}+2 \mathrm{H}_{2} \mathrm{~S}=2 \mathrm{Ag}_{2} \mathrm{~S}+2 \mathrm{H}_{2} \mathrm{O}
$$

From all silver oxides are stable only oxide (I) $\mathrm{Ag}_{2} \mathrm{O}$ and oxide (II) $\mathrm{AgO}$. Oxide (I) is formed on the silver surface as a thin film due to oxygen adsorption, which increases with increasing the temperature and pressure. Suspension of $\mathrm{Ag}_{2} \mathrm{O}$ has antiseptic properties. At a temperature of $\mathrm{t}=200{ }^{0} \mathrm{C}_{\mathrm{Ag}_{2}} \mathrm{O}$ is decomposed.

The metallic silver exhibits stability in acids. Hydrochloric acid, dilute sulfuric acid and "aqua regia" (the mixture of nitric acid and hydrochloric acid in volume ratio 1:3) do not act on the metallic silver, because the metal surface forms a protective film of silver chloride $(\mathrm{AgCl})$. Silver is good soluble in nitric acid to form soluble sodium nitrate $\left(\mathrm{AgNO}_{3}\right)$ :

$$
\mathrm{Ag}+2 \mathrm{HNO}_{3}=\mathrm{AgNO}_{3}+\mathrm{NO}_{2}+\mathrm{H}_{2} \mathrm{O}
$$

Hot concentrated sulfuric acid dissolves metallic silver to form silver sulfate $\left(\mathrm{Ag}_{2} \mathrm{SO}_{4}\right)$ (solubility of $\mathrm{Ag}_{2} \mathrm{SO}_{4}$ in water makes up 0.79 wt. $\%$ at $\mathrm{t}=20{ }^{\circ} \mathrm{C}$ ).

In aqueous solutions (solubility of $\mathrm{Ag}-0,04 \mathrm{mg} / \mathrm{l}$ ) silver ions $\mathrm{Ag}^{+}$form stable for a long time maintaining stability hydrated ions: 


$$
\mathrm{Ag}\left[\left(\mathrm{H}_{2} \mathrm{O}\right)_{2}\right]^{+}=2 \mathrm{H}^{+}+\left(\mathrm{Ag}^{+}+2 \mathrm{OH}^{-}\right)
$$

This process is due to the properties of polar water molecules to interact with each other by intermolecular dipole-dipole interactions and hydrogen bonds. As a result, $\mathrm{H}_{2} \mathrm{O}$ molecules are formed around $\mathrm{Ag}^{+}$ions the hydrated aqueous layer, capable of screening off oppositely charged ions from the interaction that is why those ions acquire higher stability in aqueous solutions.

The effectiveness of silver in comparison with other disinfection agents is shown in Figure 1.

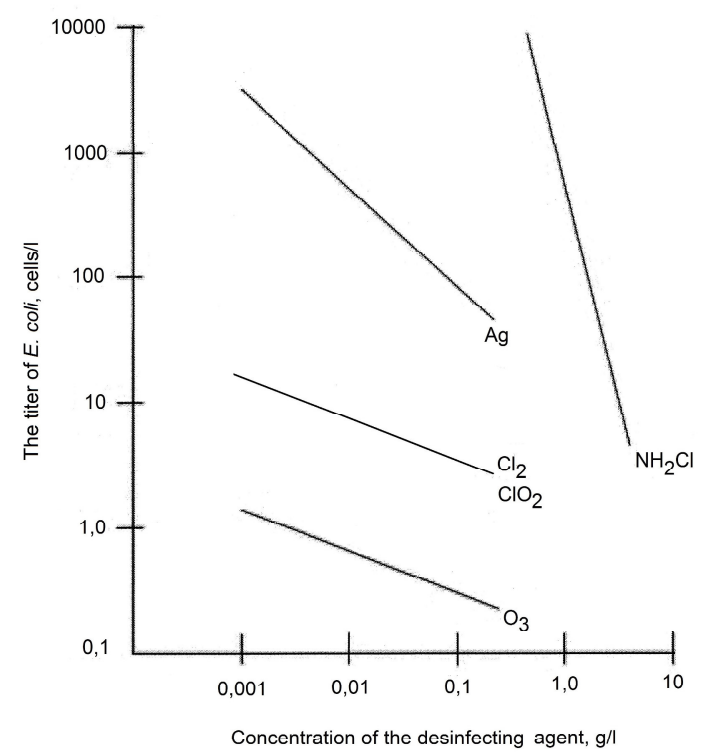

Figure 1: The rate of deactivation of E. coli by various disinfection agents

Among the numerous theories (enzymatic, adsorption, electrostatic, mutagenic) explaining the mechanism of action of $\mathrm{Ag}^{+}$ions on the bacterial cell, the most common today is currently the adsorption theory. It consists in that the bacterial cell loses the viability as a result of the interaction of electrostatic forces generated between the negative-charged cell membrane and the positively charged $\mathrm{Ag}^{+}$ions during the adsorption of $\mathrm{Ag}^{+}$by the membrane of the bacterial cell (Dondysh, 1964).

It is believed that $\mathrm{Ag}^{+}$ions are absorbed by the bacterial membrane further capable of reacting with the membrane and bacterial proteins consisting of peptidoglycan - a heteropolymer of $\mathrm{N}$-acetylglucosamine and $\mathrm{N}$ acetylmuramic acid, providing the mechanical strength and ensuring the structural and functional properties of cell membranes of bacteria and protozoa (Fig. 2).

In this process, $\mathrm{Ag}^{+}$ions interacting with the carboxyl and amino groups of peptidoglycans, to form metal complexes of protein with $\mathrm{Ag}^{+}$that has a consequence of changes in the structure and stability of peptidoglycans and is detrimental for cell's growth. This deprives peptidoglycans of the ability to transport the oxygen inside the bacterial cell, leading to hypoxia and subsequent death of the microorganism in the presence of $\mathrm{Ag}^{+}$. $\mathrm{A} \mathrm{similar}^{-}$ inhibitory effect $\mathrm{Ag}^{+}$exerts on the respiratory enzymes of microorganisms by embedding in the reaction center of the enzyme and further changing it. Since the membrane of mammalian cells does not contain peptidoglycans $\mathrm{Ag}^{+}$ions, therefore, do not affect them. 


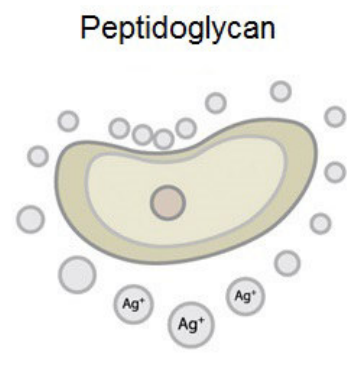

a)

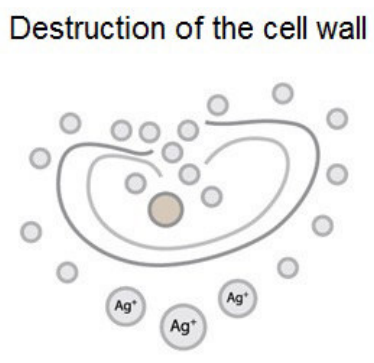

b)

Figure 2: Schematic representation of the interaction of $\mathrm{Ag}^{+}$ions with the microbial cell: a) - the interaction of $\mathrm{Ag}^{+}$ions with the membrane protein peptidoglycan; $\mathrm{b}$ ) - the process of destruction by $\mathrm{Ag}^{+}$ions the cell wall and further penetration into the microbial cell

It is known that silver can inactivate certain enzymes by binding to thiol groups, resulting in formation of silver sulfides $\left(\mathrm{Ag}_{2} \mathrm{~S}\right)$. Silver also reacts with amino, carboxyl, imidazole and phosphate groups of enzymes inhibiting the activity of glucose oxidase, $\beta$-galactosidase, lactate dehydrogenase and glutathione-peroxidase (Ma, 2009).

In the mechanism of the bactericidal effects of silver on the microbial cell an important role apparently also plays biochemical reactions catalyzed by $\mathrm{Ag}^{+}$ions, including oxidation of the bacterial cytoplasm and its subsequent degradation by oxygen in the presence of $\mathrm{Ag}^{+}$ions. Some authors explain the antimicrobial action of silver by interruption of structural and functional properties of enzymes containing interacting with $\mathrm{Ag}^{+}$ions $\mathrm{SH}-, \mathrm{NH}_{2^{-}}$and $\mathrm{COOH}$ groups, others - by interruption of the osmotic pressure in the cells as a result of interaction of $\mathrm{Ag}^{+}$ions with the cytoplasm (Woodward, 1963).

There is evidence on mutagenic properties of $\mathrm{Ag}^{+}$- the formation of metal complexes of nucleic acids with $\mathrm{Ag}^{+}$ ions and other heavy metals as gold, whereby is interrupted the spatial structure of the DNA and the ability of bacteria to divide (Criss \& Yatsimirsky, 1966). Also it is assumed that one of the causes of antimicrobial action of $\mathrm{Ag}^{+}$is the inhibition by $\mathrm{Ag}^{+}$ions the transmembrane transport of $\mathrm{Na}^{+}$and $\mathrm{Ca}^{2+}$ ions (Abramson et al., 1983).

Thus, the interaction of $\mathrm{Ag}^{+}$ions with the bacterial cell is a complex, multifactorial character affecting not only the inactivation of enzymes, but biochemical reactions, metabolism and the ability of cells to divide in the presence of $\mathrm{Ag}^{+}$.

\subsection{Preparation of micro dispersed silver nanoparticles}

The methods for preparation of metal nanoparticles having a specified size and hysic-chemical properties at the nanoscale is today one of the fastest growing areas of modern nanotechnology. The main objective is the possibility of obtaining micro dispersed nanoparticles with specified dimension with the necessary stability in solutions and external factors. At present time there have been various physical, chemical, biochemical and mixed methods for the preparation of colloidal silver micro dispersed nanoparticles (including cryochemical synthesis, cryochemical reduction, vacuum evaporation, the use of pulsed lasers etc), the main of which is the method of chemical reduction of silver derivatives. Ag nanoparticles may be prepared by chemical reduction of silver nitrate with sodium borohydride in the presence of quaternary ammonium disulfide at $200{ }^{0} \mathrm{C}$. Stable colloidal silver solutions may be prepared by reduction of silver salts with hydrogen, borohydrides and hydrazine in the presence of surfactants, e.g., sodium dodecyl sulfate. As a nucleating agent in the preparation of colloidal nanosilver (Fig. 3) is used a mesoporous aluminosilicate $\mathrm{Na}_{2} \mathrm{O} \cdot \mathrm{Al}_{2} \mathrm{O}_{3} \cdot \mathrm{nSiO}_{2} \cdot \mathrm{mH}_{2} \mathrm{O}$, where $\mathrm{n}=1-10, \mathrm{~m}$ $=1-2$, which is obtained by the hydrolysis of $\mathrm{Si}\left(\mathrm{OC}_{2} \mathrm{H}_{5}\right)_{4}$ and $\mathrm{Al}\left(\mathrm{OC}_{3} \mathrm{H}_{7}\right)_{3}$ in the presence of $\mathrm{C}_{16} \mathrm{H}_{33}\left(\mathrm{CH}_{3}\right)_{3} \mathrm{NBr}$. Next stage is the complete removal of organic components through annealing in an oxygen stream. At the final stage the aluminosilicate is impregnated with a solution of $\mathrm{AgNO}_{3}$ and reduced in a stream of hydrogen. The resulting nanocomposite exhibits high catalytic activity in the oxidation reaction of methanol (Khaydarov et al., 2009).

The most common the method of chemical reduction is used in the preparation and stabilization of micro dispersed nanoparticles of heavy metals as silver and gold in liquid phase, in aqueous and nonaqueous media (Khaydarov et al., 2009). As metal compounds are generally used their salts as reductants, as aluminum hydrides, borohydrides, hypophosphites, formaldehyde. The widespread method is due to its simplicity and accessibility. By this method may be produced silver nanoparticles with size $\sim 3.5-4.8 \mathrm{~nm}$. 
For the preparation of micro dispersed silver nanoparticles with an average size $\sim 7 \mathrm{~nm}$ is used the photochemical reduction of $\mathrm{AgNO}_{3}$ by irradiating the reaction mixture with a mercury lamp in the presence of dendrimers highly branched macromolecule consisting of a central core and the intermediate terminal repeating units of the amino $\left(-\mathrm{NH}_{2}\right)$ and a carboxyl $\left(-\mathrm{COO}^{-}\right)$groups.

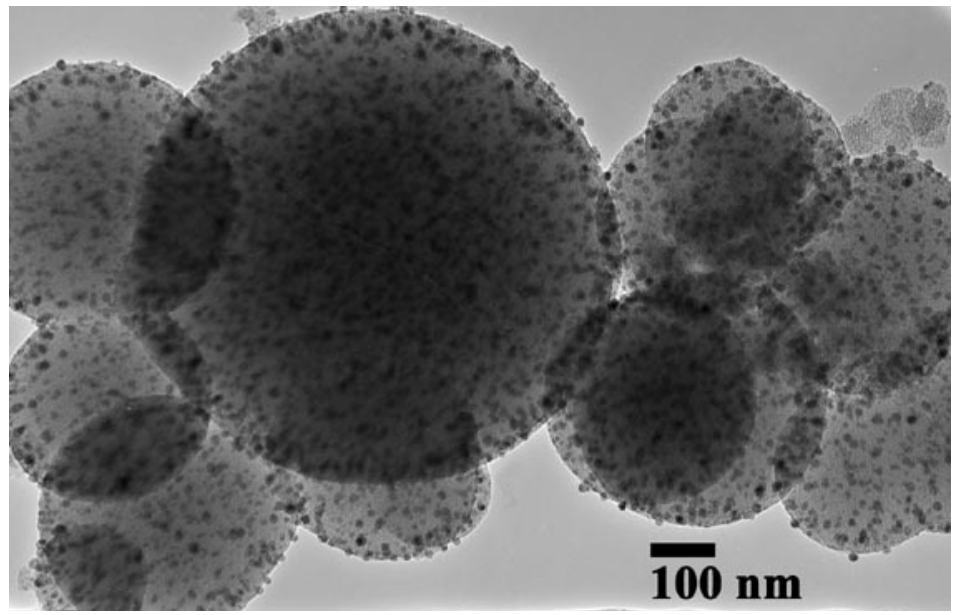

Figure 3: Electron micrographs of micro silver nanoparticles fixed on the surface of spherical particles of the mesoporous aluminosilicate $\mathrm{Na}_{2} \mathrm{O}^{\cdot} \mathrm{Al}_{2} \mathrm{O}_{3} \cdot \mathrm{nSiO}_{2} \cdot \mathrm{mH}_{2} \mathrm{O}$, where $\mathrm{n}=1-10, \mathrm{~m}=1-2$ (Rybaltovskiy at al., 2015)

Micro dispersed silver nanoparticles with an average size of $\sim 3-4 \mathrm{~nm}$ may be prepared by either biochemical or biotechnological approaches (Darroudi et al., 2011) in the aqueous solution stabilized with $\mathrm{AgNO}_{3}$ as a stabilizer and reducing organic compounds - gelatin, a mixture of polypeptides, obtained by partial hydrolysis of animal collagen protein, polyhydrates, dextran or the products of hydrolysis of cell walls of microorganisms (Fig. 4). Furthermore, some fungi and microorganisms are capable while growing in the presence of $\mathrm{Ag}^{+}$ions to produce inside the cytoplasmic space the micro dispersed flat polyhedral silver nanoparticles with sizes $\sim 50-100 \mathrm{~nm}$. Additionally, some microorganisms are capable of extracellular microbiological reduction of aqueous silver nitrate solutions to form micro dispersed silver nanoparticles with a size of $\sim 20-50 \mathrm{~nm}$.

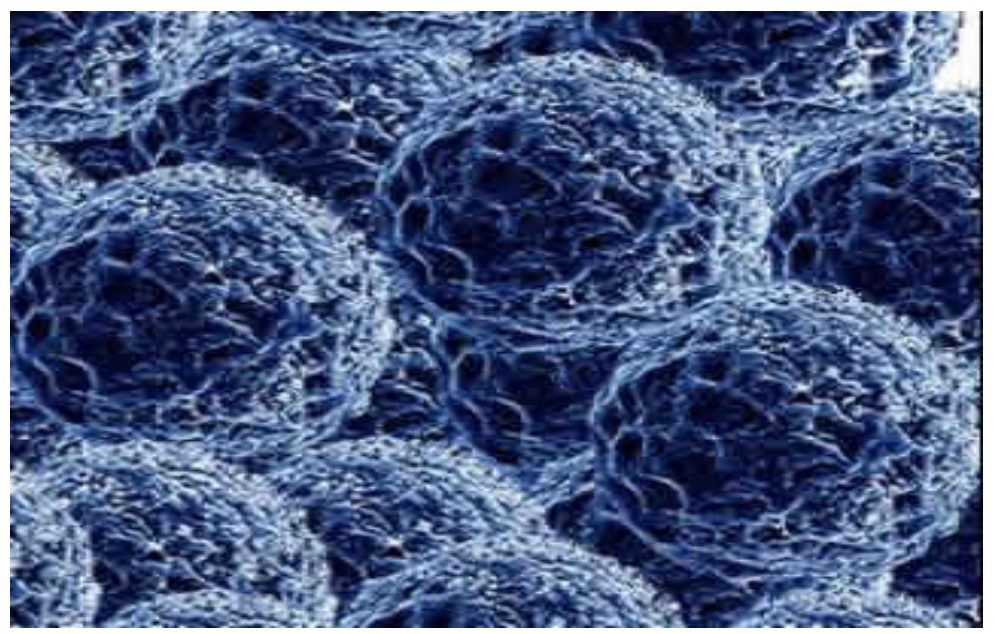

Figure 4: Electron micrographs of micro dispersed silver nanoparticles with a size of $\sim 5 \mathrm{~nm}$ on polymer matrix of gelatin (Darroudi et al., 2011)

In recent years, it become common the electrolytic method for the preparation of colloidal solutions of micro dispersed silver nanoparticles with a size of $\sim 2-7 \mathrm{~nm}$ by passing the direct electric current through the submerged silver or silver-copper electrode (anode) placed in an aprotic solvent as tetrabutyl-ammonium bromide in acetonitrile (Mosin \& Ignatov, 2013). In the electrolysis process occurs the partial dissolution of the silver anode that results that the solution is saturated with $\mathrm{Ag}^{+}$. At a given strength of electric current and electric 
voltage on the electrode the concentration of $\mathrm{Ag}^{+}$solution is determined by the time of the current source operation and the amount of the aqueous solution through which electric current is passed.

The physical-chemical properties of colloidal silver nanoparticles are determined by their aggregate and sedimentation stability, as well as the possibility to air oxidation. Wherein, the colloid stability of silver nanoparticles depends on the initial concentration of $\mathrm{Ag}^{+}$ions in solution. Dimensions of micro dispersed silver nanoparticles obtained by different methods vary within $\sim 3-100 \mathrm{~nm}$ limits. Their physical properties in the nanoscale are different from the properties of the metallic silver, in particular, the reduction of particle size leads to the lower melting temperature. Furthermore, the silver nanoparticles have extremely high specific surface area, which increases the contact area of silver with bacteria or viruses, significantly improving the bactericidal action of silver, the absorption by a cell and the transport across the cell membrane.

\subsection{Usage of micro dispersed silver nanoparticles}

The usage of silver in the form of micro dispersed nanoparticles significantly reduces the acting concentration of silver hundreds of times while maintaining bactericidal properties of silver (Mosin, 2013). Due to the ability of silver nanoparticles for a long time to keep the antibacterial properties, economically is justified their use as additives in water-based paints, lacquers, detergents, cosmetic creams and other materials that can improve the efficiency of their use and increase shelf life and storage.

Composite nanomaterials, produced by the domestic industry, based on stabilized in aqueous solutions colloidal silver nanoparticles possess inherent silver antimicrobial action in a wide range of pharmacological and in some respects (production method, efficiency, availability, low cost) are superior to their foreign counterparts. In this country recently was developed a scientific basis for the creation of new domestic nanomaterials based on $\mathrm{Ag}^{+}$ ions with desired antimicrobial properties with little change in the technological process.

The silver nanoparticles may be used to modify the traditional and new bio- and nano-materials: nanosorbents, fillers, coatings, detergents and disinfectants, including tooth pastes, detergents, soaps, creams and cosmetics. Coatings based on nanomaterials (composite, textile, paint, nanocarbon, nanosilicates), modified with silver nanoparticles can be applied as prophylactic antimicrobial protection means in problem areas where there is a risk of spread of infection: transport, public catering enterprises in areas of agricultural and livestock companies, nurseries, sports and health facilities. In conjunction with nanocarbon and nanosilicate minerals silver nanoparticles is appropriate to include in sorbents based on activated carbon impregnated with $\mathrm{Ag}^{+}$, for purification of water and destruction of pathogens in the filters of air conditioning systems, swimming pools, shower rooms and other public areas.

Another promising area of using the micro dispersed silver nanoparticles is the disinfection of water in water treatment and water treatment processes (Mosin, 2012). At the recent time in Russia are developed effective filter sorbents based on activated carbon impregnated with $\mathrm{Ag}^{+}$for cleaning and disinfection of water in homes and offices. The great practical application was received by Russian industrial and domestic electrolytic generators of colloidal silver as "Dolphin" (JSC "Eco-Atom", St. Petersburg), "Nevoton" (JSC "Nevoton", St. Petersburg), "Georgy" (JSC "Diode", Moscow). These compact devises may be used to conduct an effective water treatment and disinfection of water by $\mathrm{Ag}^{+}$in the domestic environment.

The content of $\mathrm{Ag}^{+}$in drinking water is regulated by domestic norms and standards of SanPin 2.1.4.1116-02 (SanPiN-02, 2002) (not more than $0.025 \mathrm{mg} / \mathrm{l}$ of $\mathrm{Ag}^{+}$).

\section{Conclusion}

Samples based on micro dispersed silver nanoparticles possess a broad spectrum of bactericide, bacteriostatic and antiseptic effect. They may be used in different branches of medicine for the treatment and prevention of various infectious diseases, sanitation and drinking water treatment, disinfection of swimming pools and common areas, in cosmetics - to create a stimulating creams, in the paint industry - for the production of bactericidal water-based paints and varnishes, in the manufacture of detergents, soaps and toothpastes, fillings, and as a component of the sorption filters based on activated carbon for water purification and destruction of pathogens.

\section{References}

Abramson, J.J., Trimm, J.L. \& Weden, L. (1983) Heavy metals induce rapid calcium release from sarcoplasmicreticulum vesicles isolated from skeletal muscule. Proc. Nat. Acad. Sci. USA, 80(6), 1526-1530.

Belevantsev, V.I. \& Bondarchuk I.V. (1994) Essay on the properties of silver and its compounds. The use of drugs in medicine silver /in: Proc. Institute of Inorganic Chemistry SB RAS. - Novosibirsk: Publishing 
Novosibirsk State University, pp. 89-95.

Bryzgunov, V.S., Lipin, V.N. \& Matrosov, V.R. (1964) Comparative evaluation of bactericidal properties of silver water and antibiotics on pure cultures of microbes and their associations. Proc. Kazan Medical Institute. Kazan: Kazan Medical Institute, 14, 121-122.

Chappel, J.B. \& Greville, G.D. (1954) Effect of silver ions on mitochondrial adenosinetriphosphates. Nature, $174,930-931$.

Criss, E.E. \& Yatsimirsky, K.B. (1966) Reacting nucleic acids with metals. Usp. Chem., 35(№ 2), 347-365.

Darroudi, M., Ahmad, M.B. \& Zamiri, R. (2011) Time-dependent effect in green synthesis of silver nanoparticles. International Journal of Nanomedicine, 6, 677-681.

Dondysh, L.M. (1964) Inhibitory effect of silver on some enzymatic systems. Questions and exogenous organic neuropsychiatric disorders / in Materials of scientific. Conf. State Institute of Psychiatry USSR Ministry of Health. - Moscow: State. Institute of Psychiatry USSR Ministry of Health, 2, 143-165.

Glazov, A.V., Kerin, V.V. \& Vinogradov M.A. (1986) Local combination treatment of gastroduodenal ulcers solutions by silver nitrate and a low-energy laser radiation. Current issues curative and preventive medicine /in Proc. theses. - Moscow: Science, 3, 64-67.

Ignatov, I. \& Mosin, O.V. (2013) Methods for the preparation of colloidal silver nanoparticles and spheres of their practical application field. Bulletin of Science and Education, 3, 30-42.

Khaydarov, R.A., Khaydarov, R.R. \& Estrin, Y. (2009) Silver nanoparticles: Environmental and human health impacts. Nanomaterials: Risk and Benefits (Series: NATO Science for Peace and Security Series C: Environmental Security). - Netherlands: Springer Verlag, 287-299.

Kulsky, L.A. (1987) Silver water / L.A. Kulsky, ed. - Kiev: Naukova Dumka, 104 p.

Landsdown, A.B. (2010) Silver in healthcare: Its antimicrobial efficacy and safety in use / A.B. Landsdown, ed. - Cambridge: Royal Society of Chemistry, 217 p.

Loginov, A.F., Bezlepko A. \& Tsyrik V.A. (1999) Evaluating the effectiveness of silver ions in the treatment of gastric ulcer and 12 duodenal ulcer / Abstracts scientific-practical conference of Main military clinical hospital N.N. Burdenko "Opportunities and prospects of aggressive therapy and plastic reconstructive surgery". Moscow: MMCH N.N. Burdenko, 125-126.

Ma, S., Mu, J., Qu, Y. \& Jiang, L. (2009) Effect of refluxed silver nanoparticles on inhibition and enhancement of enzymatic activity of glucose oxidase. Colloids and Surfaces A: Physicochemical and Engineering Aspects, 345( 1-3), 101-105.

Mironenko, Y.P. (1972) Treatment of influenza by ionized solutions of metallic silver. Chemoprophylaxis and chemotherapy of influenza / Proc. $1^{\text {st }}$ All-Union Symp. for chemoprevention and chemotherapy of influenza. Leningrad, 23-25 June 1971. - Leningrad: LGU Publishing, 116-118.

Mosin, O.V. (2012) Silver in water treatment components. S.O.K. Sanitary technique, heating, air conditioning. - Moscow: "Media Technology", 7, 26-31.

Mosin, O.V. (2013) Bactericidal properties of colloidal silver nanoparticles. Nanotechnology. Ecology. Production, 6, 54-59.

Mosin, O.V. \& Ignatov, I. (2013) Methods for the preparation of colloidal silver nanoparticles and their practical use. Nanoengineering, 5, 23-30.

Mosin, O.V. \& Ignatov, I. (2014) Methods for the preparation of colloidal silver nanoparticles. Nano and Microsystems, 2, 46-52.

Nägeli, K.W. (1893) Über oligodynamische Erscheinungen in lebenden Zelle. Neue Denkschr. Allgemein. Schweiz. Gesellsch. Ges. Naturwiss, Bd. XXXIII, 1, 134-139. 
Obukhov, A.V. (1992) Effect of collargol on the immune response in vitro. Colloidal Silver. Physico-chemical properties. Applications in medicine / in Proc. Institute of Catalysis G.K. Boreskov. Sib. Dep. Russian Academy of Sciences, 53, 53-56.

Obukhov, A.V. (1994) Prospects for the use of drugs for the treatment by silver HIV. The use of drugs of silver in medicine. Preprint № 3. - Novosibirsk: Institute of Clinical Immunology RAMS. Sib. Dep. Russian Academy of Sciences, 6-12.

Rybaltovskiy, A.O., Ishenko, A.A., Zavorotny, Y.S., Garshev, A.V., Dorofeev, S.G., Kononov, N.N. \& Minaev, N.V. (2015) Synthesis of photoluminescent $\mathrm{Si} / \mathrm{SiO}_{\mathrm{x}}$ core/shell nanoparticles by thermal disproportionation of SiO: structural and spectral characterization, Journal of Materials Science, 50(5), 2247-2256.

Roschin, A.V. \& Ordzhonikidze, E.K. (1984) Silver - some aspects of its toxicokinetics. Occupational hygiene and prof. diseases, 10, 25-28.

Sanitary rules and regulations SanPiN-02 (2002) "Drinking water and water supply of populated areas", Ministry of Health of Russian Federation. - Moscow. 2002. 45 p.

Savadyan, E.Sh., Melnikov, V.M. \& Belikov, G.P. (1989) Modern trends in the use of silver-containing antiseptics. Antibiotics and chemotherapy, 11, 874-878.

Shahverdy, A.R., Fakhimi, A. \& Minaian, S. (2007) Synthesis and effect of silver nanopracles on the antibacterial activity of different antibiotics against Staphylococcus and Escherichia coli. NanomedicineNanotechnology biology and medicine, 3(2), 168-171.

Shrestha R., Joshi, D.R. \& Gopali, J (2009) Oligodynamic fraction of silver, copper and brass on enteric bacteria isolated from water of Kathmandu Valley. Nepal Journal of Science and Technology, 10, 189-193.

Vaynar, A.I. (1960) The biological role of trace elements in animals and humans / A.I. Vaynar, ed. - Moscow: Nauka, 542 p.

Vitsyn, V.A., Ostashevsky, A.T. \& Blagitko, E.M. (1976) Treatment of patients with surgical sepsis intravenous injection of ammonia solutions of silver. Surgery, 11, 129-132.

Volski, N.N., Seledtzov, V.I. \& Lyubimov, G.Y. (1992) Immunomodulatory properties of colloidal silver products. Colloidal Silver. Physico-chemical properties. Applications in medicine. - Novosibirsk: Novosibirsk Institute of Catalysis G.K. Boreskov. Sib. Dep. RAS, 53, 31-52.

Woodward, R.L. (1963) Review of the bactericidal effectiveness of silver. Am. Water Works Assotiation, 55(7), 881-886. 